\title{
SEPARATION AND CHARACTERIZATION OF MAJOR OXIDATIVE IMPURITY IN FIMASARTAN DRUG SUBSTANCE
}

\author{
Charu P. Pandya ${ }^{1}$ and Sadhana J. Rajput ${ }^{1, *}$ \\ ${ }^{1}$ Department of Pharmaceutical Quality Assurance, Faculty of Pharmacy, The Maharaja \\ Sayajirao University of Baroda, Center of Relevance and Excellence in New Drug Delivery \\ System, Government of India, Vadodara (Gujarat) 390002, \\ *E-mail: sjrajput@gmail.com
}

\begin{abstract}
In the stress degradation studies of Fimasartan, one major unknown oxidative degradation impurity was identified by LC-MS. This impurity was separated by preparative HPLC. By spectral data analysis $\left({ }^{1} \mathrm{H}\right.$ NMR, ${ }^{13} \mathrm{C}$ NMR, DEPT, MS/MS and IR), this impurity is characterized as 2-(1-((2'-(1H-tetrazol-5-yl)-[1,1'-biphenyl]-4-yl)methyl)2-butyl-1,6 -dihydro-4-methyl-6-oxo-pyrimidin-5-yl)-N,N-dimethylacetamide. The details of stress studies, identification, isolation, characterization, formation and mechanism of this impurity are discussed and presented here.
\end{abstract}

Keywords: Fimasartan, Degradation, Identification, Isolation, Characterization

๑ RASĀYAN. All rights reserved

\section{INTRODUCTION}

Fimasartan (FIMA) (Fig.-1) is an antihypertensive agent. It is ninth non-peptide angiotensin II receptor antagonist $(\mathrm{ARB})^{1}$. It is also used for the treatment of heart failure. Fimasartan acts by blocking angiotensin II receptor type I (AT1 receptor). Fimasartan is pyrimidin-4(3H)-one derivative of losartan which is obtained by replacement of imidazole ring in losartan. Fimasartan has higher potency and longer duration than losartan. Fimasartan was approved in South Korea in September 9, 2010. It is marketed as Kanarb by Boryung Pharmaceuticals in Korea. It is available as a tablet for oral use which contains $60 \mathrm{mg}$ or $120 \mathrm{mg}$ of Fimasartan potassium trihydrate ${ }^{2}$. It is approved in India by CDSCO in 2016. HPLC method has been developed for evaluation of stability and simultaneous determination of fimasartan and amlodipine in tablet dosage form ${ }^{3}$. UPLC tandem mass chromatographic method has been reported for determination of fimasartan in human plasma ${ }^{4}$. Literature has been reported on LC-MS method development for the estimation of fimasartan in human plasma ${ }^{5-7}$. Literature has been reported on pharmacokinetics and metabolite profiling of fimasartan ${ }^{8}$.

Recently we have developed a stability indicating method development of Fimasartan ${ }^{9}$. Major degradation was observed in oxidative condition. The objective of this study was to identify the major degradation product in oxidative condition after its isolation and characterization by mass, NMR and IR.

\section{Chemical Reagents and Solutions}

\section{EXPERIMENTAL}

Fimasartan (FIMA) standard drug was obtained from Angene Chemical Ltd (China). HPLC grade Acetonitrile was purchased from Rankem Pvt. Ltd., Mumbai. Chemicals used in the analysis were potassium dihydrogen ortho phosphate(AR grade), ortho phosphoric acid, formic acid purchased from Loba Chemie Pvt. Ltd., Mumbai. Hydrogen peroxide $\left(\mathrm{H}_{2} \mathrm{O}_{2}\right) 30 \%$ v/v was purchased from S.D. Fine Chemical Ltd, Mumbai.

\section{Preparation of Mobile Phase}

$10 \mathrm{~mm}$ phosphate buffer ( $\mathrm{pH} 3$ ) was prepared by dissolving $1.37 \mathrm{~g}$ of potassium dihydrogen phosphate in sufficient double distilled water to produce $1000 \mathrm{ml}$ and then the $\mathrm{pH}$ of the buffer was adjusted to 3.0 with

Rasayan J. Chem., 11(3), 1042-1049(2018) http://dx.doi.org/10.31788/RJC.2018.1132083

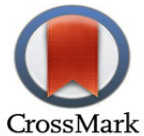


ortho phosphoric acid. Composition of mobile phase was having phosphate buffer and acetonitrile in the ratio of 50:50.

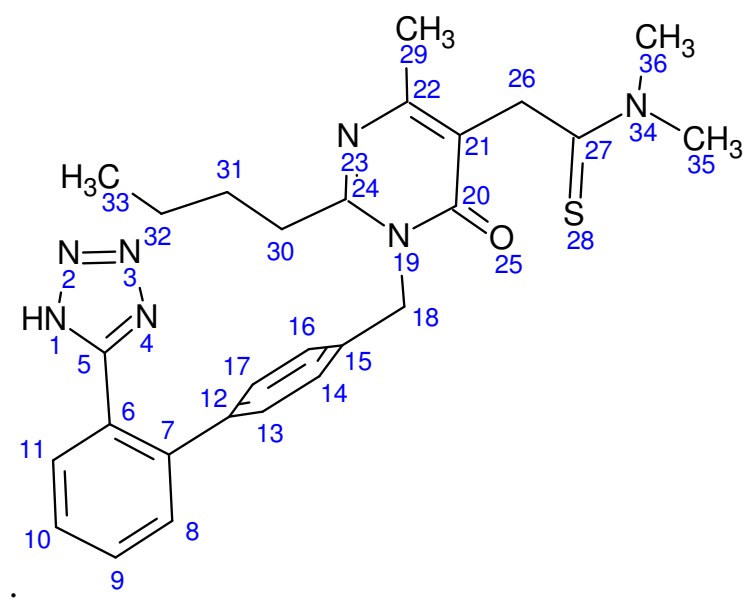

Fimasartan

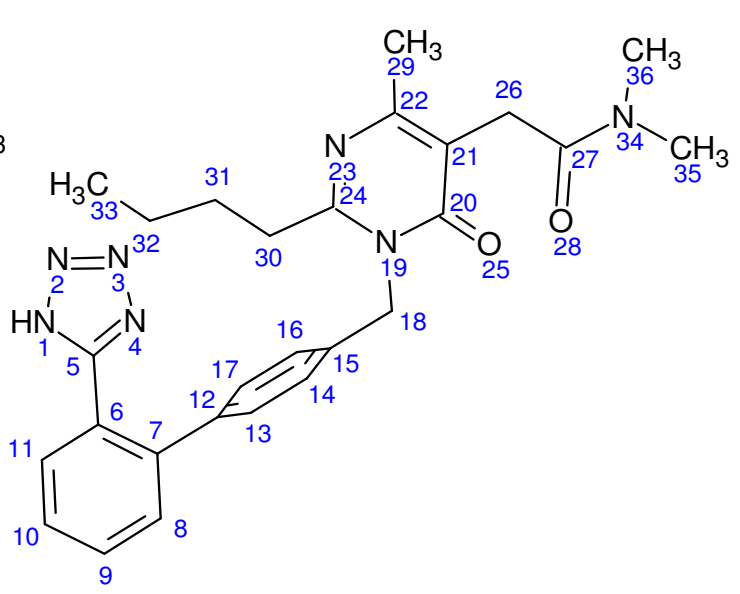

Degradation Product (DP)

Fig. -1: Structure of FIMASARTAN (FIMA) and Degradation Product(DP)

\section{Instrumentation and Chromatographic Conditions \\ LC- PDA}

The method was performed on a Shimadzu Prominence HPLC system containing an LC-20AD binary pump, Shimadzu SPD M-20A PDA detector. Samples were injected with a fixed loop of $20 \mu \mathrm{L}$ Rheodyne 7725 injector valve with a flow rate of $1 \mathrm{ml} / \mathrm{min}$. Data analysis was performed with LC solutions software (Shimadzu Corporation, Kyoto, Japan).The method was developed on a Hypersil BDS C-18 column $(5 \mu \mathrm{mX} 250 \mathrm{mmX} 4.6 \mathrm{~mm}$ i.d.).The flow rate was $1 \mathrm{ml} / \mathrm{min}$. Detection was performed at $262 \mathrm{~nm}$. Before analysis, the mobile phase was filtered through $0.2 \mu$ nylon N 6,6 membrane filter and sonicated for 5 min.

\section{LC-UV (Preparative)}

Chromatographic separation was performed on Shimadzu (Shimadzu Corporation, Kyoto, Japan), a chromatographic system equipped with Shimadzu LC-20 AP binary pump and Shimadzu SPD-20A detector. Samples were injected through Rheodyne 7725 injector valve. Data acquisition was performed with Class VP software. Daisogel-SP-100-10-ODS-P column was used for isolation. The flow rate kept at $5 \mathrm{ml} / \mathrm{min}$. Detection was performed at $262 \mathrm{~nm}$. The mobile phase in LC-PDA was replaced with $0.1 \%$ formic acid and acetonitrile in the ratio of 45:55.

\section{LC-MS}

LC-MS was performed on LCQ fleet (Thermo Fischer Scientific instrument).The system was coupled with quaternary system delivery module in positive and negative ESI (Electro Spray Ionization). The nebulizer pressure was set at $20 \mathrm{psi}$. The gas temperature was set at capillary voltage $5500 \mathrm{~V}$ using nitrogen gas and gas temperature was set at $250^{\circ} \mathrm{C}$ using drying gas nitrogen at 30 psi pressure. Data acquisition was done with Xcalibur software. The mobile phase containing $10 \mathrm{~mm}$ phosphate buffer $\mathrm{pH} 3$ in LC-PDA was replaced by $0.1 \%$ formic acid and acetonitrile in the ratio of 45: 55 in LC-MS.

\section{NMR Spectroscopy}

${ }^{1} \mathrm{H}$ and ${ }^{13} \mathrm{C}$ NMR spectra of FIMA and its degradation product were recorded by using Bruker Avance II 400 NMR spectrometer that consisted of dual broad band probe and z-axis gradients. DMSO- $\mathrm{d}_{6}$ was used 
as a solvent for analysis. ${ }^{1} \mathrm{H}$ and ${ }^{13} \mathrm{C}$ NMR chemical shifts were calculated on $\delta$ scale in ppm with respect to tetramethyl silane as internal standard $(\delta 0.00 \mathrm{ppm})$.

\section{FT-IR Spectroscopy}

FT-IR spectra were recorded as Schimadzu 8400s FT-IR spectrometer.

\section{Isolation of Oxidative Degradation Sample}

Our previous studies ${ }^{9}$ have shown that FIMA undergoes extensive oxidative degradation. Efforts were made to use stronger conditions so as to achieve total degradation of FIMA and obtain the impurity in a pure state. For this, a solution of FIMA $(500 \mathrm{mg}$ ) dissolved in $15 \mathrm{~mL}$ of water and acetonitrile in $25 \mathrm{~mL}$ of volumetric flask. To the solution was added $10 \mathrm{ml}$ of $30 \%$ hydrogen peroxide. The solution for degradation was kept at room temperature for 48 hours.

\section{Confirmation of Full Degradation of FIMA}

\section{RESULTS AND DISCUSSION}

The oxidative degradation sample was diluted to the required concentration and analyzed with analytical high-performance liquid chromatography. The analytical HPLC chromatograms of FIMA is shown in Fig. 2. FIMA eluted about a retention time of $7.3 \mathrm{~min}$. HPLC chromatogram of a stressed sample of oxidative degradation sample is shown in Fig.-3. Degradation product (DP) was eluted at 4.9 min and was found with a maximum degradation of $75.4 \%$. The degradation product was purified by preparative HPLC. Fractions greater than $95 \%$ were collected together and concentrated on rotavapour to remove acetonitrile. The solution was kept in lyophilizer overnight. DP was obtained with colorless solid and was recrystallized with hot water. The isolated fraction was analyzed by analytical HPLC which shows complete removal of FIMA which confirms the presence of DP only which is shown in Fig.-4.

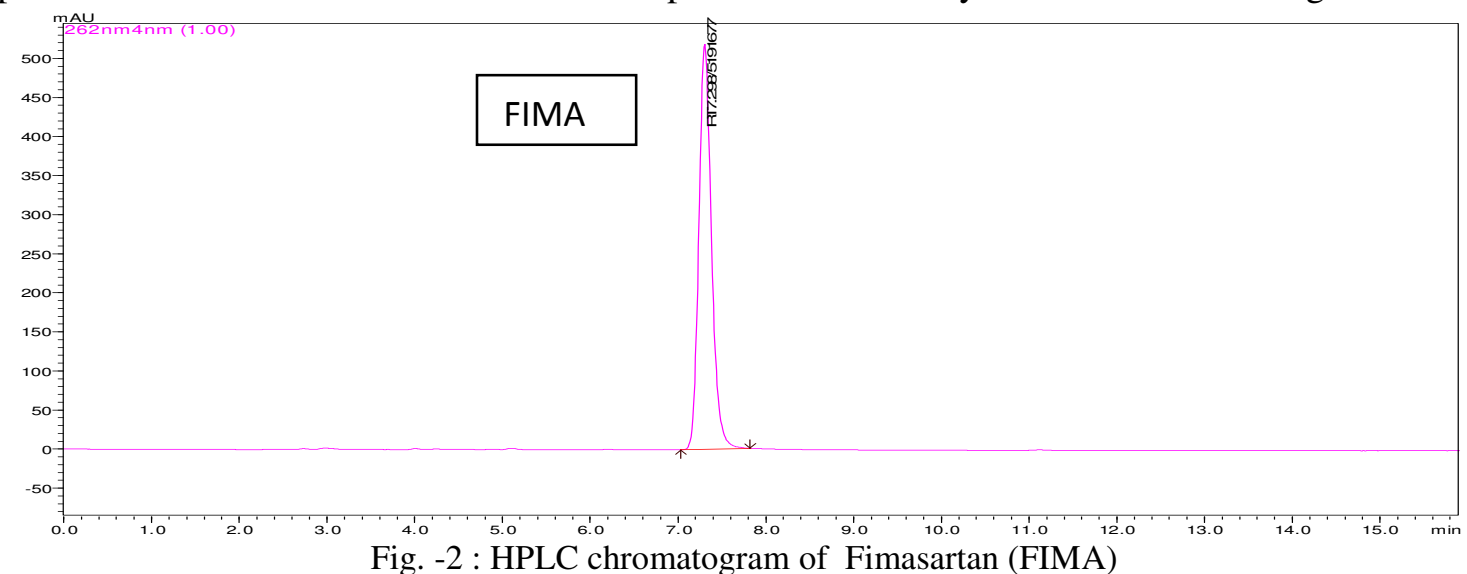

Fig. - 2 : HPLC chromatogram of Fimasartan (FIMA)

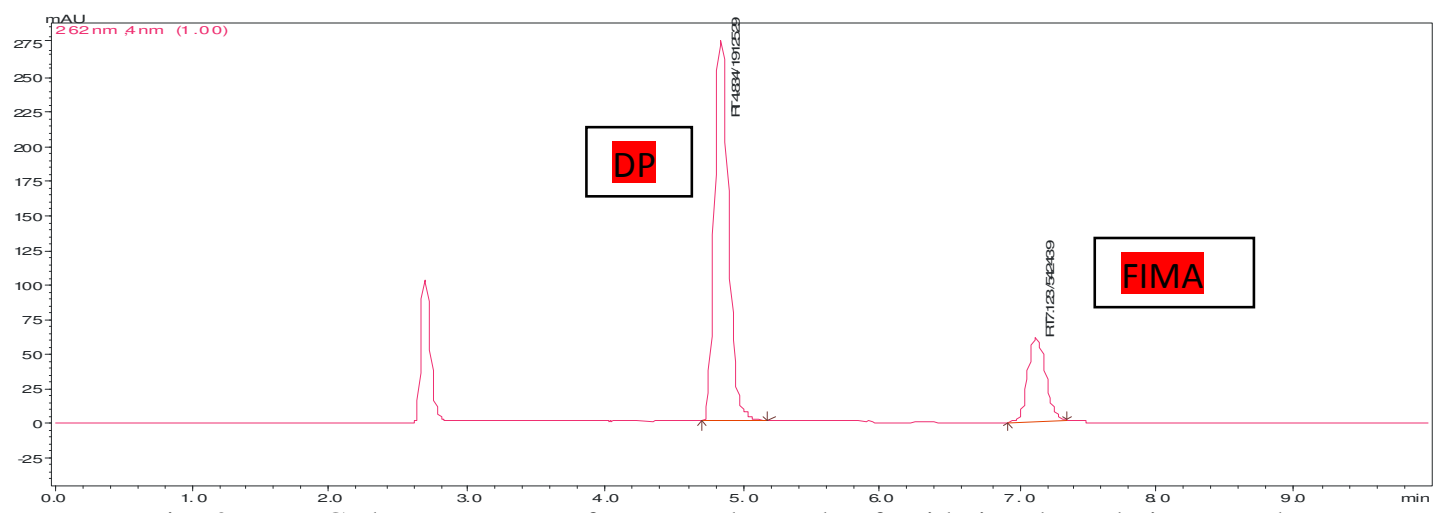

Fig.-3 : HPLC chromatogram of a stressed sample of oxidative degradation sample 


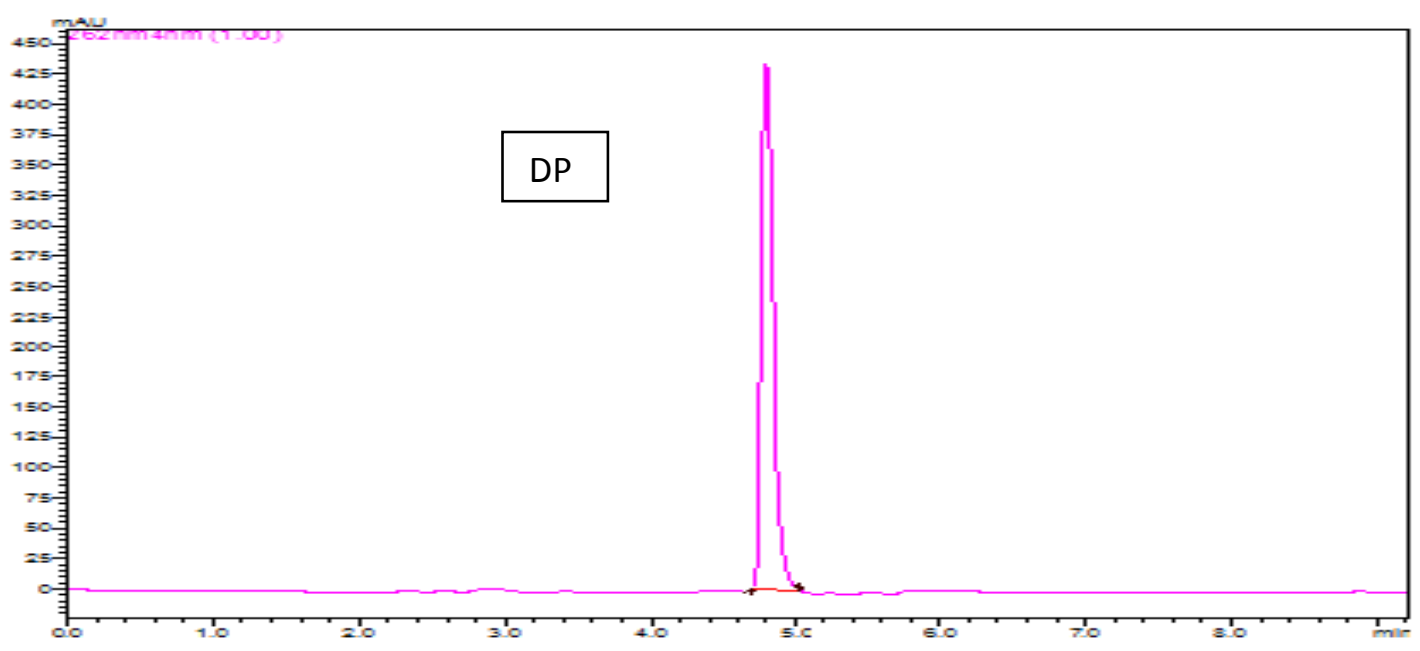

Fig. -4 : HPLC Chromatogram of isolated major oxidative degradation product

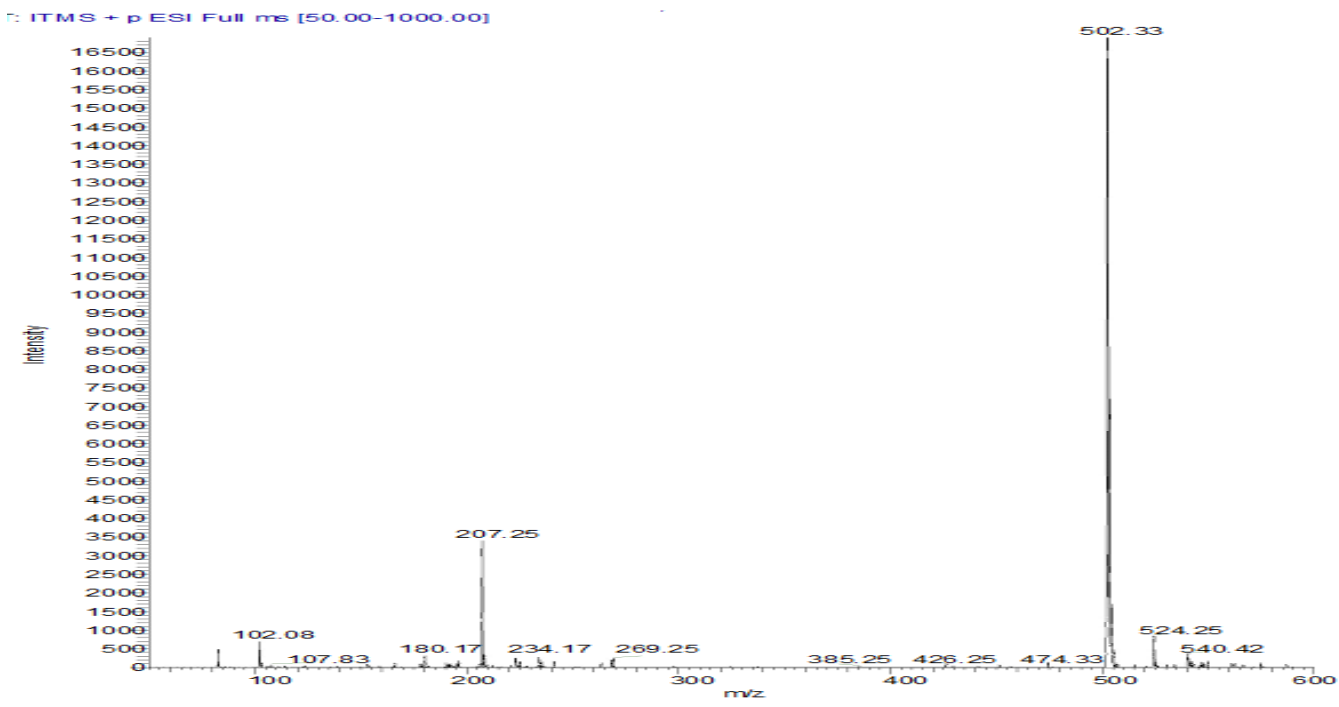

Fig.-5- Mass spectrum of FIMA

\section{Identification of Oxidative Degradation Sample by LC-MS}

To get structural insight, the LC-MS analysis was carried out on the oxidatively stressed sample. The mass spectrum thus obtained showed a protonated molecular ion of degradation impurity at $\mathrm{m} / \mathrm{z} 486$ (Fig.-6), whereas the FIMA displayed protonated molecular ion at m/z 502 (Fig.-5) Thus the degradation impurity DP has 16 amu less than the molecular ion of FIMA.

The ${ }^{1} \mathrm{H}$ NMR, ${ }^{13} \mathrm{C}$ NMR and DEPT spectral data of degradation product were compared with those of FIMA in Table-1. The numbering scheme for the NMR assignments is shown in Fig-1. In ${ }^{1} \mathrm{H}$ NMR, a number of protons in FIMA and its degradation product is the same.As in ${ }^{13} \mathrm{C}-\mathrm{NMR}$, the presence of $\mathrm{C}=\mathrm{S}$ (Thione) group carbon at 27th position in FIMA, is $199 \mathrm{ppm}$. In DP, there is the disappearance of $\mathrm{C}=\mathrm{S}$ (Thione) group and formation of carbonyl group at 27th position is observed, which is indicated by the chemical shift at $168.98 \mathrm{ppm}$. DEPT spectrum of FIMA and DP shows the presence of four methyl groups (positive). DEPT spectrum of FIMA and DP reveals the presence of five methylene groups (negative). Thus the degradation impurity structure can be rationalized in terms of substitution of thio group by a carbonyl group. The electrospray ionization (ESI) mass spectrum of the DP (Fig. 6) showed a molecular ion peak at $\mathrm{m} / \mathrm{z}, 486.25 \mathrm{amu}[\mathrm{M}+\mathrm{H}]^{+}$in positive ion mode, whereas the FIMA (Fig.5), exhibited protonated molecular ion at $\mathrm{m} / \mathrm{z}$ 502. Thus the degradation impurity DP has 16 amu less than the molecular ion of FIMA indicating replacement of sulphur group by oxygen. IR absorption spectral 
RASĀYAN J. Chem.

Vol. 11 | No. 3 |1042 - 1049 | July - September | 2018

data of degradation impurity (Table-2) also supporting that formation of one carbonyl functional group at $1651 \mathrm{~cm}^{-1}$ and disappearance of thione $(-\mathrm{C}=\mathrm{S})$ functional group at $1230 \mathrm{~cm}^{-1}$. The IR $(\mathrm{KBr})$ spectral data of the degradation impurity was compared with those of FIMA in Table-2. From the spectral data, the structure of this degradation impurity is characterized as 2-(1-((2'-(1H-tetrazol-5-yl)-[1,1'-biphenyl]-4yl)methyl)-2-butyl-4-methyl-6-oxo-1,6-dihydropyrimidin-5-yl)-N,N-dimethylacetamide with molecular formula $\mathrm{C}_{27} \mathrm{H}_{31} \mathrm{~N}_{7} \mathrm{O}_{2}$ and molecular weight 485.25 .

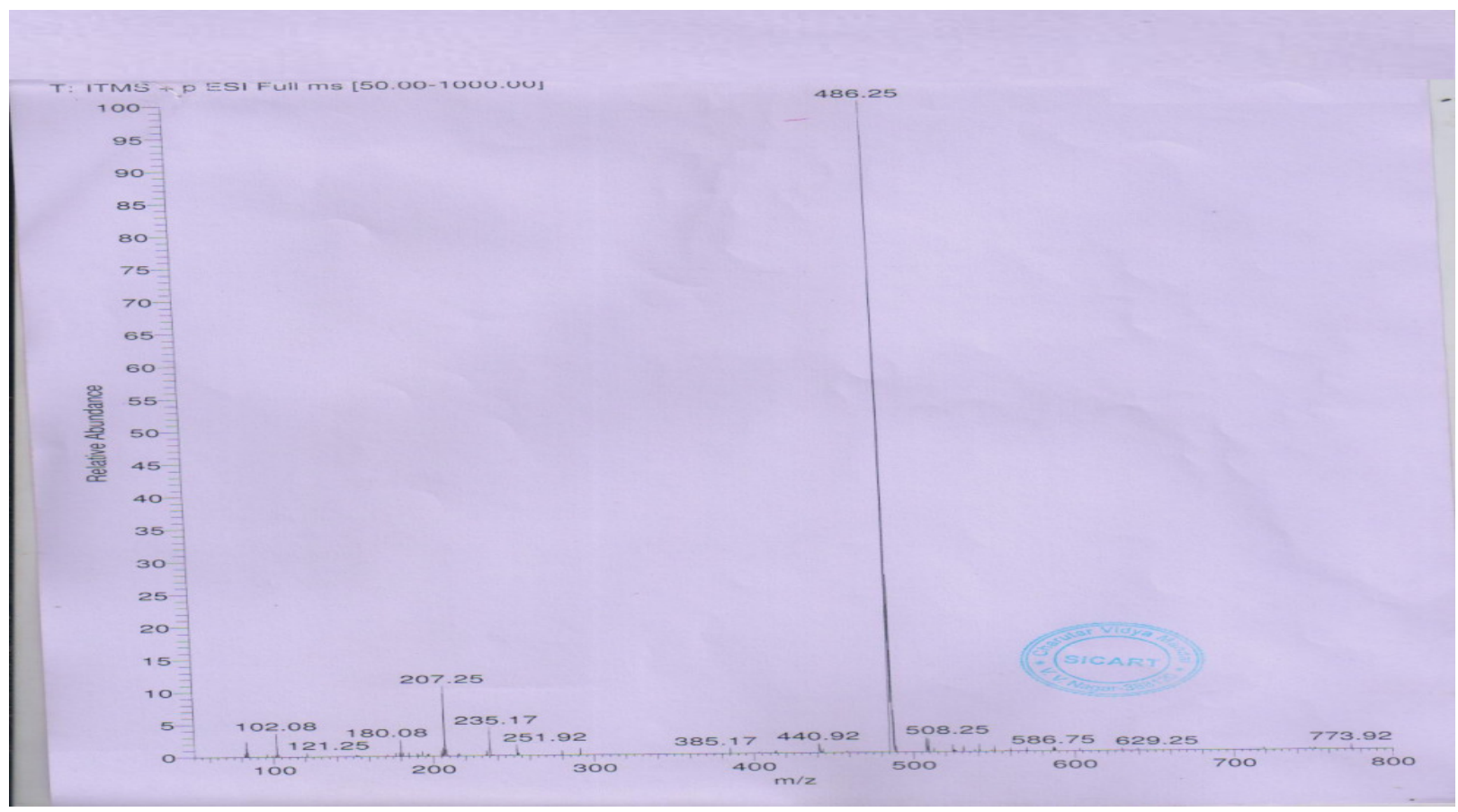

Fig.-6- : Mass spectrum of DP

Table-1: NMR Assignments of FIMA and DP

\begin{tabular}{|c|c|c|c|c|c|c|c|c|c|}
\hline \multicolumn{5}{|c|}{ FIMA } & \multicolumn{5}{|c|}{ DP } \\
\hline Position & ${ }^{1} \mathrm{H}$ & $\begin{array}{l}\text { Chemic } \\
\text { al } \\
\text { Shift }(\delta \\
\text { ppm })\end{array}$ & ${ }^{13} \mathrm{C}$ & DEPT & $\begin{array}{l}\text { Positio } \\
\text { n }\end{array}$ & ${ }^{1} \mathrm{H}$ & $\begin{array}{l}\text { Chemic } \\
\text { al } \\
\text { Shift }(\delta \\
\text { ppm })\end{array}$ & ${ }^{13} \mathrm{C}$ & DEPT \\
\hline 1 & -- & -- & -- & --- & 1 & --- & ---- & -- & --- \\
\hline 2 & -- & -- & -- & --- & 2 & -- & -- & -- & -- \\
\hline 3 & -- & -- & -- & -- & 3 & -- & -- & -- & -- \\
\hline 4 & -- & -- & & & 4 & -- & & & \\
\hline 5 & -- & -- & 161.86 & $\begin{array}{l}\text { Quaternary } \\
\text { Carbon }\end{array}$ & 5 & -- & -- & 162 & $\begin{array}{l}\text { Quaternary } \\
\text { Carbon }\end{array}$ \\
\hline 6 & -- & -- & 134.21 & $\begin{array}{l}\text { Quaternary } \\
\text { Carbon }\end{array}$ & 6 & -- & & 134 & $\begin{array}{l}\text { Quaternary } \\
\text { Carbon }\end{array}$ \\
\hline 7 & -- & -- & 132.27 & $\begin{array}{l}\text { Quaternary } \\
\text { Carbon }\end{array}$ & 7 & & & 135 & $\begin{array}{l}\text { Quaternary } \\
\text { Carbon }\end{array}$ \\
\hline 8 & $1 \mathrm{H}$ & $7.3, \mathrm{~m}$ & 125.40 & $-\mathrm{CH}-$ & 8 & $1 \mathrm{H}$ & $7.58, \mathrm{~m}$ & 122.25 & $-\mathrm{CH}-$ \\
\hline 9 & $1 \mathrm{H}$ & $7.36, \mathrm{~m}$ & 130.45 & $-\mathrm{CH}-$ & 9 & $1 \mathrm{H}$ & $7.57, \mathrm{~m}$ & 131.03 & $-\mathrm{CH}-$ \\
\hline 10 & $1 \mathrm{H}$ & $7.4, \mathrm{~m}$ & 130.00 & $-\mathrm{CH}-$ & 10 & $1 \mathrm{H}$ & $7.65, \mathrm{~m}$ & 130.54 & $-\mathrm{CH}-$ \\
\hline 11 & $1 \mathrm{H}$ & $7.5, \mathrm{~m}$ & 129.26 & $-\mathrm{CH}-$ & 11 & $1 \mathrm{H}$ & $7.65, \mathrm{~m}$ & 129.09 & $-\mathrm{CH}-$ \\
\hline 12 & - & - & 140.82 & $\begin{array}{l}\text { Quaternary } \\
\text { Carbon }\end{array}$ & 12 & -- & -- & 140.95 & $\begin{array}{l}\text { Quaternary } \\
\text { Carbon }\end{array}$ \\
\hline 13 & $1 \mathrm{H}$ & 7.06, dd & 127.42 & $-\mathrm{CH}-$ & 13 & $1 \mathrm{H}$ & $7.08, \mathrm{~s}$ & 127.79 & $-\mathrm{CH}-$ \\
\hline
\end{tabular}


RASĀYAN J. Chem.

Vol. 11 | No. 3 |1042 - 1049 | July - September | 2018

\begin{tabular}{|c|c|c|c|c|c|c|c|c|c|}
\hline 14 & $1 \mathrm{H}$ & $6.8, \mathrm{dd}$ & 127.42 & $-\mathrm{CH}-$ & 14 & $1 \mathrm{H}$ & $7.08, \mathrm{~s}$ & 127.79 & $-\mathrm{CH}-$ \\
\hline 15 & -- & --- & 139.87 & $\begin{array}{l}\text { Quaternary } \\
\text { Carbon }\end{array}$ & 15 & -- & & 138.23 & $\begin{array}{l}\text { Quaternary } \\
\text { Carbon }\end{array}$ \\
\hline 16 & $1 \mathrm{H}$ & $6.9, \mathrm{dd}$ & 126.71 & $-\mathrm{CH}-$ & 16 & $1 \mathrm{H}$ & $7.08, \mathrm{~s}$ & 126.26 & $-\mathrm{CH}-$ \\
\hline 17 & $1 \mathrm{H}$ & $7.08, \mathrm{dd}$ & 126.71 & $-\mathrm{CH}-$ & 17 & $1 \mathrm{H}$ & $7.08, \mathrm{~s}$ & 126.26 & $-\mathrm{CH}-$ \\
\hline 18 & $2 \mathrm{H}$ & $5.2, \mathrm{~s}$ & 32.13 & $-\mathrm{CH}_{2}$ & 18 & $2 \mathrm{H}$ & $5.25, \mathrm{~s}$ & 33.20 & $-\mathrm{CH}_{2}$ \\
\hline 19 & -- & ---- & --- & ---- & 19 & -- & -- & -- & $\begin{array}{l}-- \\
-\end{array}$ \\
\hline 20 & -- & -- & 160.74 & --- & 20 & -- & -- & 162.00 & -- \\
\hline 21 & -- & -- & 119.02 & $\begin{array}{l}\text { Quaternary } \\
\text { Carbon }\end{array}$ & 21 & -- & -- & 116.46 & $\begin{array}{l}\text { Quaternary } \\
\text { Carbon }\end{array}$ \\
\hline 22 & -- & --- & 158.15 & $\begin{array}{l}\text { Quaternary } \\
\text { Carbon }\end{array}$ & 22 & -- & -- & 159.31 & $\begin{array}{l}\text { Quaternary } \\
\text { Carbon }\end{array}$ \\
\hline 23 & -- & --- & --- & --- & 23 & --- & -- & -- & \\
\hline 24 & --- & --- & 159.17 & $\begin{array}{l}\text { Quaternary } \\
\text { Carbon }\end{array}$ & 24 & -- & -- & 155.01 & $\begin{array}{l}\text { Quaternary } \\
\text { Carbon }\end{array}$ \\
\hline 25 & --- & --- & & & 25 & -- & -- & -- & \\
\hline 26 & $2 \mathrm{H}$ & $3.79, \mathrm{~s}$ & 32.18 & $-\mathrm{CH}_{2}$ & 26 & $2 \mathrm{H}$ & $3.54, \mathrm{~s}$ & 33.27 & $-\mathrm{CH}_{2}$ \\
\hline 27 & --- & --- & $199^{20}$ & & 27 & -- & -- & 168.98 & \\
\hline 28 & -- & -- & -- & & 28 & -- & -- & -- & \\
\hline 29 & $3 \mathrm{H}$ & $2.15, \mathrm{~s}$ & 20.32 & $-\mathrm{CH}_{3}$ & 29 & $3 \mathrm{H}$ & $2.21, \mathrm{~s}$ & 21.51 & $-\mathrm{CH}_{3}$ \\
\hline 30 & $2 \mathrm{H}$ & $2.63, \mathrm{t}$ & 20.5 & $-\mathrm{CH}_{2}$ & 30 & $2 \mathrm{H}$ & $2.50, \mathrm{t}$ & 21.58 & $-\mathrm{CH}_{2}$ \\
\hline 31 & $2 \mathrm{H}$ & $1.5, \mathrm{q}$ & 27.05 & $-\mathrm{CH}_{2}$ & 31 & $2 \mathrm{H}$ & $1.56, \mathrm{q}$ & 28.14 & $-\mathrm{CH}_{2}$ \\
\hline 32 & $2 \mathrm{H}$ & $1.3, \mathrm{q}$ & 29.26 & $-\mathrm{CH}_{2}$ & 32 & $2 \mathrm{H}$ & $1.29, \mathrm{q}$ & 30.36 & $-\mathrm{CH}_{2}$ \\
\hline 33 & $3 \mathrm{H}$ & $0.824, \mathrm{t}$ & 12.45 & $-\mathrm{CH}_{3}$ & 33 & $3 \mathrm{H}$ & $0.80, \mathrm{t}$ & 13.58 & $-\mathrm{CH}_{3}$ \\
\hline 34 & -- & -- & -- & -- & 34 & -- & -- & -- & -- \\
\hline 35 & $3 \mathrm{H}$ & $3.44, \mathrm{~s}$ & 33.68 & $-\mathrm{CH}_{3}$ & 35 & $3 \mathrm{H}$ & $2.83, \mathrm{~s}$ & 36.80 & $-\mathrm{CH}_{3}$ \\
\hline 36 & $3 \mathrm{H}$ & $3.45, \mathrm{~s}$ & 33.92 & $-\mathrm{CH}_{3}$ & 36 & $3 \mathrm{H}$ & $3.05, \mathrm{~s}$ & 35.04 & $-\mathrm{CH}_{3}$ \\
\hline
\end{tabular}

Refer Fig.-1 for numbering, s- singlet, m-multiplet, dd-double doublet, q-quartet

Table-2: FTIR Spectral Data of Fimasaration and Degradation Product

\begin{tabular}{|c|c|c|c|}
\hline \multicolumn{2}{|c|}{ FIMA } & \multicolumn{2}{|r|}{ DP } \\
\hline Wave number $\left(\mathrm{cm}^{-1}\right)$ & Functional group & $\begin{array}{l}\text { Wave number } \\
\left(\mathrm{cm}^{-1}\right)\end{array}$ & Functional group \\
\hline 2958 & \multirow{3}{*}{$\begin{array}{c}\text { Broad peak covering } \\
\mathrm{NH} \text {, Aromatic } \mathrm{C}-\mathrm{H} \text {, } \\
\mathrm{CH}_{3} \text { (Stretching) and } \\
\mathrm{CH}_{2} \text { (Stretching) }\end{array}$} & 3308 & Tetrazole N-H \\
\hline 2931 & & 3192 & Aromatic C-H \\
\hline 2713 & & 2967,2955 & $\mathrm{CH}_{3}$ Stretching \\
\hline 1741 & Pyrimidine amide & 2928 & $\mathrm{CH}_{2}$ Stretching \\
\hline 1616 & \multirow{3}{*}{$\begin{array}{c}\text { Aromatic } \mathrm{C}=\mathrm{C} \\
\text { (Stretching) }\end{array}$} & 1740 & Pyrimidine Amide \\
\hline 1537 & & 1651 & $\begin{array}{l}\text { Tertiary Amide } \\
\text { formation }\end{array}$ \\
\hline 1481 & & 1537 & Aromatic $\mathrm{C}=\mathrm{C}$ \\
\hline 1481 & Aromatic $\mathrm{C}=\mathrm{N}$ & 1460 & Aromatic $\mathrm{C}=\mathrm{C}$ \\
\hline 1356 & Aromatic C-N & 1402 & Hetero Aromatic $\mathrm{C}=\mathrm{C}$ \\
\hline 1230 & $\mathrm{C}=\mathrm{S}$ Stretching & 1359 & C-N Stretching \\
\hline 1185 & $\mathrm{C}-\mathrm{N}$ & 1230 & $\mathrm{C}=\mathrm{S}$ disappeared \\
\hline 835 & \multirow{2}{*}{$\begin{array}{l}\text { Out of plane } \mathrm{C}-\mathrm{H} \\
\text { bending }\end{array}$} & 1180 & C-N Stretching \\
\hline 778 & & 825 & $\begin{array}{l}\text { Out of plane } \mathrm{C}-\mathrm{H} \\
\text { bending }\end{array}$ \\
\hline 600 & Substituted Aromatic & & \\
\hline
\end{tabular}




\section{Formation of Degradation Impurity}

The degradation impurity formed in the presence of oxidative stress degradation is due to the replacement of sulphur by oxygen and formation of the carbonyl group. The probable fragmentation pathway is shown in Fig.-7.

\section{CONCLUSION}

The major unknown oxidative degradation product was isolated and was characterized by using spectroscopic techniques namely NMR,ESI-MS and IR. The spectral studies indicate that $\mathrm{C}=\mathrm{S}$ group is replaced by $\mathrm{C}=\mathrm{O}$ during oxidative degradation. The hitherto unreported impurity has been identified as 2(1-((2'-(1H-tetrazole-5-yl)-[1,1'-biphenyl]-4-yl)methyl)-2-butyl-1,6-dihydro-4-methyl-6-oxo-1,6dihydropyrimidin-5-yl)-N,N-dimethylacetamide and its fragmentation route has been predicted.

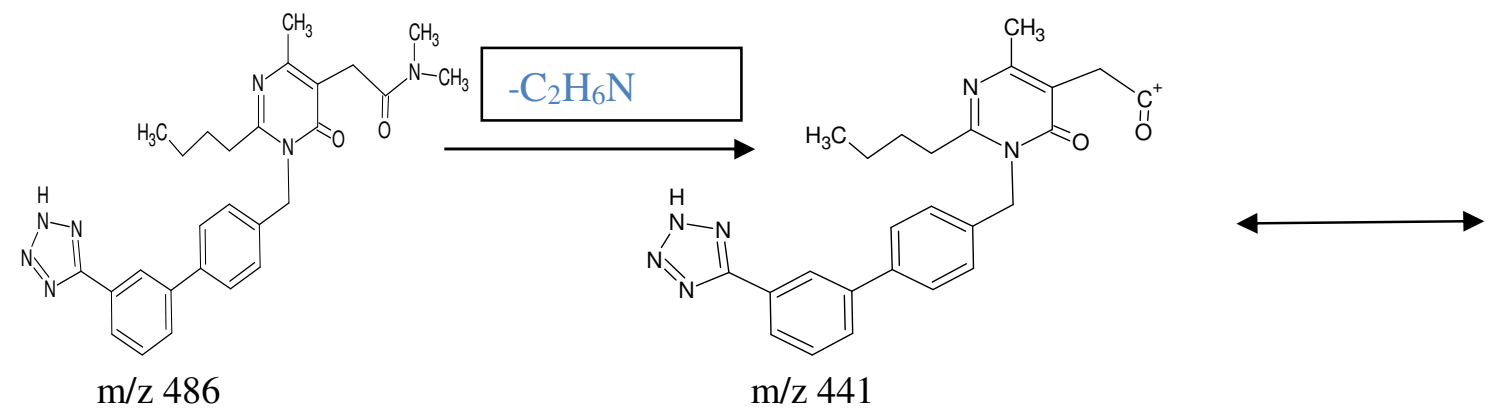<smiles>CCCCc1nc(C)c(CC(=O)[O-])c(=O)n1Cc1ccc(-c2cccc(-c3nn[nH]n3)c2)cc1</smiles><smiles>CCCCc1nc(C)c(C)c(=O)n1Cc1ccc(-c2cccc(-c3nn[nH]n3)c2)cc1</smiles>

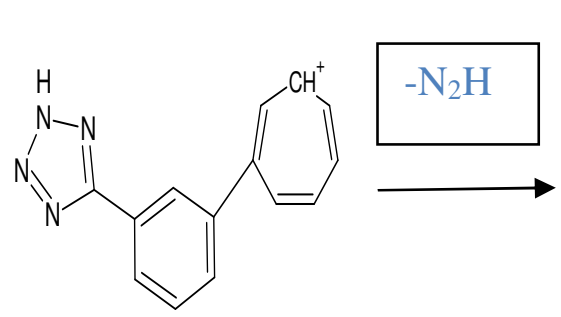

$\mathrm{m} / \mathrm{z} 235$<smiles>[C+]1C=CC=CC(c2cccc(C3=N[N-]3)c2)=C[CH+]1</smiles>

$\mathrm{m} / \mathrm{z} 208$

Fig.-7: Proposed Fragmentation Pathway of Degradation Product

\section{REFERENCES}

1. H.Y. Lee and B.H. Oh, Drugs, 76, 1015 (2016), DOI: 10.1007/s40265-016-0592-1.

2. J. B. Park, K.C. Sung, S. M. Kang and E.J. Cho , Amer. J of Cardiovas. Drugs, 13, 47 (2013), DOI: 10.1007/s40256-013-0004-9.

3. H.W. Moon, A.M. Yousaf, K.H. Cho, C.S. Yong, J.O. Kim and H.G. Choi, Asian J. of Pharma. Sci., 9(3), 123(2014), DOI: 10.1016/j.ajps.2014.04.002.

4. J.Y. Hyun, H.J. Kim, M.R. Gwon, H.W. Lee and S.J. Seong, Ana. Sci., 31, 1335(2015). 
5. D-H Kim , J-H Lee ,W-S Shim and K.T. Lee, J Pharma Care Health Sys, 4, 52(2017), DOI: 10.4172/2376-0419-C1-021.

6. S.H. Yoon, S. Oh, S.H.Kim, S.J. Yi, K.S. Yu, I.J. Jang and J.Y. Chu, J of Chromato. Sci., 53(8), 1250 (2015), DOI: 10.1093/chromsci/bmu219

7. B.S. Shin, T.H. Kim, S.H. Paik,Y.H. Chi, J.H. Lee, H.K. Tan, Y. Choi, M. Kim and S.D. Yoo , Biomed. Chromatography,25, 1208 (2011), DOI: 10.1002/bmc.1592.

8. T.H. Kim ,S. Shin, M. Bashir ,Y.H. Chi, S.H. Paik, J.H. Lee, H.J. Choi, S.D. Yoo, J.B. Bulitta, E.Ma, S.H. Joo and B.S.Shin, Xenobiotica, 44, 913(2014), DOI:10.3109/00498254.2014.915359.

9. C.P. Pandya and S.J.Rajput, Indo American J. of Pharm. Research, 7, 929 (2017).

10. V. Yankov, D. Tsvetkova, D. Obreshkova, S. Ivanova and V. Petkova, World J of Pharmacy and Pharm. Sci,. 5,18 (2016), DOI: 10.20959/wjpps20166-7105.

11. J. Mamta and N. Devanna, Rasayan J. of Chem., 11(1),300(2018), DOI: 10.7324/RJC.2018.1112007.

12. P.A. Kumar, Y.R. Kumar and A. Jayshree, Rasayan J. of Chem., 9 (2), 180 (2016).

13. V.V. Reddy, G. Gowardhan, K. Srinavasulu, G.M. Reddy, V. Himabindu, Rasayan J. of Chem., 1(2), 301 (2008).

14. K. Ramulu, B.M. Rao and N. Someswara Rao, Rasayan J. of Chem., 6(4), 274(2013).

15. D. Suneetha and A. Lakshamanarao, Rasayan J. of Chem., 3(1), 117 (2010).

16. M. Bakshi and S. Singh, J. Pharm Biomed Anal., 28,1011(2002), DOI: 10.1016/S07317085(02)00047-X.

17. M. Bakshi and S. Singh, Pharma Tech On-line, 1(2000).

18. ICH. Validation of analytical procedures: Text and methodology Q2(R1), International Conference on Harmonization, 2005.

19. ICH. Stability testing of new drug substances and products Q1A(R2), International Conference on Harmonization, 2003.

20. M. Badertscher, Structure Determination of Organic compound, Fourth Edition, Sprineger,p.127.

[RJC-2083/2018] 